\title{
物理的環境ストレスが誘発する内耳障害
}

\author{
大神 信孝 $* 1,2$, 押野 玲奈 $* 1$, 二宮 裕将 $* 1$, 李 香 $* 1$, 加藤 昌志 $* 1$ \\ *1 名古屋大学大学院医学系研究科環境労衝衛生学 \\ $*^{2}$ 中部大学次世代食育センター
}

\section{Impairments of Inner Ears Caused by Physical Environmental Stresses}

\author{
Nobutaka OHGAMI*1,2, Reina OSHINO*1, Hiromasa NINOMIYA*1, Xiang LI*1 and Masashi KATO*1 \\ ${ }^{*}$ Department of Occupational and Environmental Health, Nagoya University Graduate School of Medicine \\ *2Nutritional Health Science Research Center, Chubu University
}

\begin{abstract}
The inner ears contain the organ of Corti, vestibule and semicircular canal. The organ of Corti is crucial for hearing, while the vestibule and semicircular canal play important roles in maintaining balance. Exposure to noise at excessive levels is known to cause damages of the inner ears, resulting in noise-induced hearing loss. On the other hand, noise levels (dB) are used for the evaluation of health risks by exposure to noise, although noise consists of sound with broad frequencies $(\mathrm{Hz})$. Thus, information about the frequencydependent effect of noise on health is largely unknown. In this review, we first introduce noise-induced hearing loss caused by exposure to audible noise. We then describe the imbalance in mice exposed to low-frequency noise $(100 \mathrm{~Hz})$.
\end{abstract}

Key words: low-frequency noise（低周波騒音), hearing loss（難聴）, imbalance（平衡感覚異常）, inner ear (内耳), neurodegeneration（神経変性）

はじめに

騒音は音量（デシベル； dB） と周波数（ヘルッ； $\mathrm{Hz}$ ) により表される物理的環境因子である。ヒトの可聴域 $(20 \sim 20,000 \mathrm{~Hz})$ とマウスの可聴域 $(1,000 \sim 40,000 \mathrm{~Hz})$ は部分的に重なるが，騒音性難聴が誘発される聴覚障害 のリスクは主にヒトの可聴域音の音量により評価されて いる。近年, エコキュートや風力発電, あるいは空調機 器の室外機など様々な機器から発生している低周波騷音 が社会問題となっている。しかしながら, 周波数の要素 己加光て評価した騒音の健康りスクの情報は限られてい る。本稿では, 内耳機能涼響を与える物理的環境因子

受付 2016 年 8 月 23 日, 受理 2016 年 9 月 15 日

Reprint requests to: Nobutaka OHGAMI, PhD

Department of Occupational and Environmental Health, Nagoya University Graduate School of Medicine, 65 Tsurumai-cho, Showaku, Nagoya, Aichi 487-8501, Japan

TEL: +81(52)744-2123, FAX: +81(52)744-2124

E-mail: nobugami@med.nagoya-u.ac.jp
として騒音を取り上げ，騒音が誘発する健康りスクにつ いて筆者らの実験研究の成果もまじえて紹介したい。

\section{内耳の構造}

側頭骨内に存在する内耳は, 聴覚に必須の蝸牛, おょ び平衡感覚に重要な前庭や半規管から成る感覚器である (1)。蝸牛の内部には中央階と呼ばれる管状の渦巻き構 造が存在し, その管内にコルチ器が存在する。蝸牛の外 観はカタッムリの款状の骨包と呼ばれる硬組織につつま れた形態を呈する（図 1)。骨包の内部に存在するコル 于器は主に三つの構成部位から成る。一つ目は䋐毛を持 つ有毛細胞であり, メカノトランスダクションと呼ばれ る音刺激の電気信号への変換に重要な役割を持つ。有毛 細胞の他, 支持細胞や蓋膜飞存在し，それらが協調的に 機能して音を受容している。二つ目は血管条であり，有 毛細胞のメカノトランスダクション機能に必須の内リン パ電位の維持に重要な役割を担っている。血管条は, 辺 縁細胞，中間細胞と呼ばれる色素細胞，基底細胞の 3 層 
から成る構造を持ち，その中に多数の血管が存在する。 三つ目は，有毛細胞からの電気信号を伝導するラセン神 経節である。ラセン神経節の周囲にはシュワン細胞が包 むように存在し (2), シュワン細胞に発現するコネキシ ンなどのノックアウトマウスでは, 脱髄により先天性難 聴の表現型を呈する。これらの部位のらち, どれか一つ の部位の機能が失われるだけでも, 内耳は重度の機能低 下を招き，聴覚障害を発症する事が示されている(3)。 蝸牛は上から久て頂回転から基底回転までらせん状に回 転した構造をもつ。そのらせん状構造に沿って, 前述し たコルチ器が存在する。コルチ器には二種類の有毛細胞 が存在するが，フラスコ様の形状をもつ内有毛細胞は一 列に，円柱様の形状をもつ外有毛細胞は三列で，基底回
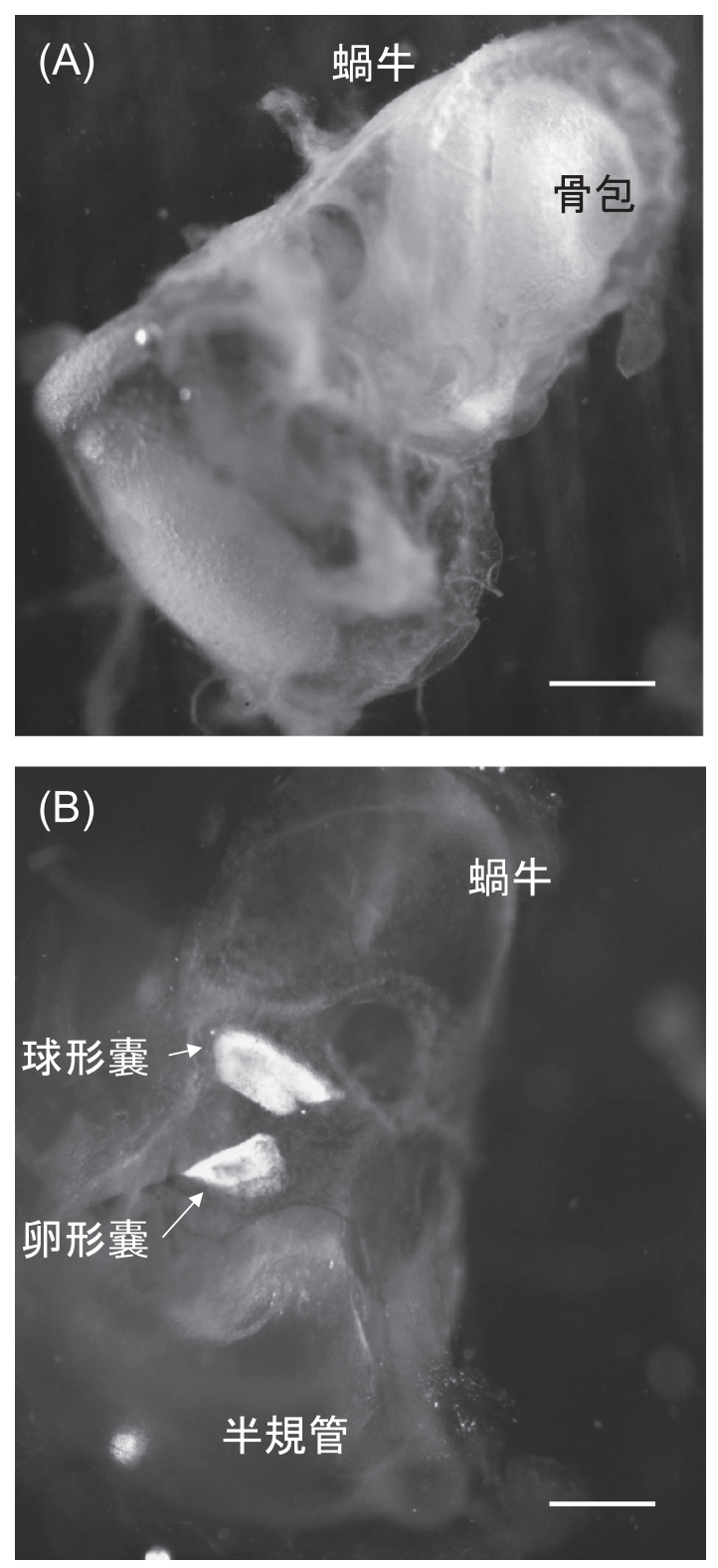

図 1 マウスの内耳。（A）実体顕微鏡下で撮影したマウスの内 耳。(B) サリチル酸メチル処理法（25）で透明化した内耳。球 形囊と卵形囊の部位に平衡斑が観察される。Scale bars: $500 \mu \mathrm{m}$.
転から頂回転にいたるまで整然と配置されている。基底 回転部のコルチ器は高音域の音を，頂回転部は低音域の 音の認識に重要である事が知られている。加齢性難聴の 典型的な症状として高音域から聴力が低下していく事が 知られているが，加齢性難聴を発症したマウスは基底回 転部のコルチ器の構成細胞から欠落していく事が知られ ている(4)。内有毛細胞には otoferlin と呼ばれるタンパ ク質が発現して扔り，この分子が核となって神経化学物 質がリボン状に束礼られた「リボンシナプス」といら特 有のシナプス構造で神経化学物質を開口分泌し，膨大な 音情報を中枢神経系に伝達している事が報告されている (5)。外有毛細胞は遠心性の聴神経系とシナプスを形成 する。一方，内耳には前庭空と呼ばれる穴があり，前庭 空が入り口となっている内耳の空洞は前庭と呼ばれ，蝸 牛と半規管の間に存在する。前庭空は耳小骨 (アブミ骨) で蓋をされており，その近傍に蝸牛空が存在する。前庭 は主に卵形囊と球形囊から構成され，内リンパ液が充填 されて扣り，膜迷路をつらじて各々半規管と蝸牛管につ ながっている。卵形囊と球形囊は平衡感覚に重要な感覚 器であり，それぞれ平衡斑と呼ばれる部位が存在する (図 1)。平衡斑は有毛細胞, 耳石と耳石膜から構成され, 卵形囊の平衡斑は垂直方向に，卵形囊の方は水平方向に 配置されている。これらの配置方向により，我々は平行 方向や垂直方向の直線的な重力や加速度を感受してい る。有毛細胞の絨毛の先端にはゼラチン状の耳石膜が存 在し，その膜に碁石様の耳石が保持されている特有の形 態を呈している。耳石は炭酸カルシウムとカルシウム結 合タンパク質により構成されている(6)。

\section{騒音性難聴の現状}

大音量の騷音に曝露される機会は，工場や重機を扱う 現場で働く労働者に限らず，近年のポータブルミュー ジックプレイヤーなどの普及に伴い，若者に限らず多く の人で増加している（7）。騒音に曝露された結果，騒音 性難聴が誘発される事は知られているが，上述した背景 などにより患者数は増加傾向にあり，現時点でも世界で 数億人にのぼると推計されている (1)。騒音性難聴は急 性と慢性の難聴に分類される。急性の騷音性難聴は射撃 音や爆音，雷などの衝撃音により誘発される。一方，慢 性騒音性難聴は比較的マイルドな音が長期間曝露される 事により誘発され職業性難聴とも呼ばれる。そのリスク が増大する騒音レベルの閾值は， $85 \mathrm{~dB}$ 以上（等価騷音 レベル）とされている（6）。8 時間以上， $85 \mathrm{~dB}$ の騒音 に連続して曝露されると, 内耳の聴神経系に器質的影響 を与え，聴覚に不可逆的な影響を与える (permanent threshold shift; PTS)。一方， $85 \mathrm{~dB}$ の騒音でも短時間で 一時的な騒音曝露による聴覚障害は可逆的である事が知 られている (temporary threshold shift; TTS) (8)。PTS も TTS も主たる障害部位は内耳である。米国での調査によ ると，4,000万人以上の労働者が騒音性難聴のリスクが増 
大するレベルの騒音に日常的に曝露されて扣り, 実に労 働者の 4 人に 1 人の割合で職業性難聴が発症すると推計 している (8)。しかしながら，個人レベルで騒音性難聴 を予防する方法として，耳栓やイヤーマフなど騒音を物 理的に遮音する方法は広く実用化されているものの, そ 孔以外には有効な予防方法はなく, 一旦騒音によって発 症した騒音性難聴を治療することは難しい状況である。

\section{騒音性難聴の実験研究}

騒音性難聴の標的臟器は内耳であるが，ヒトレベルで 病理解析を実施するのは実質不可能であるため, 実験動 物に騒音を曝露する実験研究が実施されている。過去の 研究によると, 騒音性難聴が発症した内耳コルチ器では, 有毛細胞に扔いて酸化ストレスが上昇し, 神経変性が誘 発される事が示されている(9-12)。騒音曝露で酸化ス トレスが上昇する理由としては以下の説が提唱されてい る。有毛細胞で音刺激を電気信号に変換する際に多量の エネルギーを要する事が知られている(9)。エネルギー の供給源の一つは細胞内のミトコンドリアの電子伝達系 であるが，好気的呼吸で酸素が消費される際の副産物と して「スーパーオキシド」も産生される。この副産物の 産生が騒音による酸化ストレス上昇の一因であると考光 られている (9)。つまり, 音量が小さい場合は, スーパー オキシドが産生されてもグルタチオンや抗酸化酵素など によりレスキューされる一方，音量が大きい場合は，大 音量を処理する有毛細胞のエネルギー消費量も増大し, 副産物のスーパーオキシド産生量も増加する。その結果, 抗酸化酵素による処理が追いつかなくなり, 酸化ストレ スが増大寸ると考光られている(9)。過去の報告による と, グルタチオンレベルを制御する sirtuin3 を過剩発現 させたトランスジェニックマウスが騒音性難聴侸耐性を 示す事が報告されている(13)。また，神経変性予防に有 効な事が報告されている nicotinamide adenine dinucleotide $\left(\mathrm{NAD}^{+}\right)$の前駆体の nicotinamide riboside（NR）のマウ スへの腹腔内投与が, 上述した $\operatorname{sirtuin} 3$ 依存的に騒音性 難㯖に予防効果を示す事, 更浪騒音曝露後の投与でもレ スキュー効果を示す事が報告されている（13）。その他, 有毛細胞のペルオキシソームの抗酸化活性は騒音に対す る内耳の防御機構に重要である事が示されている(14)。 ヒトを対象にした試験では, n-acetyl cysteine（NAC）な ぞの抗酸化物質のヒトへの投与による騒音性難聴の予防 試験が進められているおり（15），今後上述した分子を標 的にした予防試験も実施されていく事が予想される。

\section{低周波騒音の現状}

低周波騒音は $100 \mathrm{~Hz}$ 以下の周波数を持つ騒音と定義 される。低周波騷音の周波数は七トの可聴域 $(20 \sim$ $20,000 \mathrm{~Hz})$ 飞部分的に含まれるが, マウスの可聴域 $(1,000$ 〜 40,000 Hz) には全く含まれない(図2)。このことから，

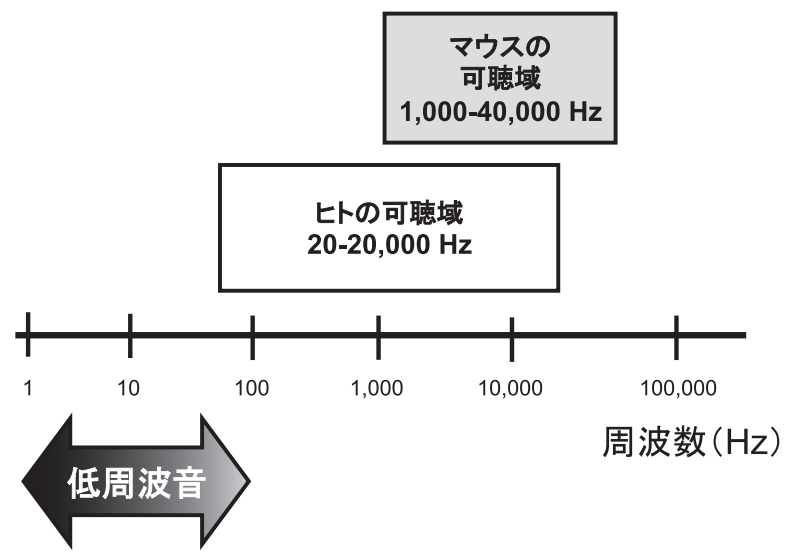

図 2 ヒトとマウスの可聴音の周波数域と低周波騷音

基本的に低周波騒音に曝されているか認識しにくく, 我々は無意識飞低周波騒音飞曝されている可能性があ る。一方，低周波騒音はエコキュートや風力発電，ある いは空調機器の室外機なぞ様々な機器から発生して抢 り, それらの機器の近傍に居住する住民が体調不良を訴 光て抢り，社会問題となっている。屋内に扔いても， フ リーザー, エアコンや換気扇等から $100 \mathrm{~Hz}$ の周波数を ピークとする低周波騒音が約 $70 \mathrm{~dB}$ の音量で発生してい る(16)。つまり, 我々は日常生活の中で低周波騒音に 曝されている可能性がある。しかしながら，低周波騒音 の具体的な健康リスクについては情報が限られている。 一方，低周波騒音は高周波波域の音と比較して減衰しに くい物理的性質を持ち，上述した可聴域騷音を遮音でき るイヤーマフや耳栓などでは低周波騒音を遮音出来な い。重く分厚い材質のものなら遮音できる可能性はある が, 今の所，七トが装着可能な，低周波騷音の遮音に有 効な耳栓などの防護品は実用化されていない。工場など で使用する大型機器からも低周波騒音は発生する為, 低 周波騒音の曝露を軽減する事が重要であるが，日本では 低周波騒音の健康りスク評価法もなく，環境基準値も設 定されていないのが現状である。

\section{低周波騒音による平衡感覚障害の実験研究}

ヒトを対象にした平衡感覚の生理機能測定として，重 心動摇，足踏久検查，眼振検查などが挙げられる。マウ スを対象にした実験研究では，ローターロッド，平均台 歩行試験, 強制水泳試験, 歩行パターン解析, 姿勢反射 試験なぞの行動解析と平衡感覚の感覚器である前庭や半 規管膨大部の病理解析を組久合わせて平衡感覚を評価し ている(17-20)。過去の実験研究によると, Espin と呼 ばれる細胞骨格系タンパク質をノックアウトした遺伝子 改変マウスでは, 平衡感覚に重要な前庭の有毛細胞の䋐 毛構造が維持できない事が報告されている(21)。また, 有毛細胞の䄉毛の先端部に乗っている耳石の形成異常を 示すNox3ノックアウトマウスは重度のバランス障害の 
表現型を示し (22), 細胞外マトリックスの構成タンパ ク質 alpha-tectorin の遺伝子改変マウスでは, 耳石を保 持する耳石膜の形態異常を示す事が報告されている (23)。このように, 平衡感覚に重要な感覚器の形成や生 理機能に重要な分子は徐々に明らかにされつつある。一 方，これまでに平衡感覚障害を誘発する抗生物質などの 化学物質は明らかになっているが, 物理的環境因子につ いては殆ど情報がない。また，前述した可聴域騒音が内 耳機能に影響を与え, 騒音性難聴を誘発する事はよく知 られているが，低周波騒音が内耳機能にどのような影響 を与えるか分かっていない。そこで, 我々は低周波騷音 に注目し，野生型マウスに同様の低周波騷音（70 dB， $100 \mathrm{~Hz}$ )を 1 ヶ月程度曝露する実験研究を実施した。低 周波騒音の曝露条件は我々が実施した環境測定の測定值 を参考にした（16）。曝露されたマウスはロータロッド, 平均台試験や歩行パターンの異常, 前庭の有毛細胞の形 態異常と酸化ストレスの上昇を伴い, 平衡感覚異常を示 す事が示唆された（16）。前述したように，コルチ器の 有毛細胞では，可聴域の音刺激を電気信号に变換する際 に必要なエネルギー産生の副産物として，スーパーオキ シドが産生されると考兄られている(9)。前庭の有毛細 胞に拈いても同様の機序で酸化ストレスが上昇されるの かについて, 今後の検討課題である。また，過去の報告 によると, マウスの可聴音域よりも低い周波数の $375 \mathrm{~Hz}$ の音刺激により野生型マウスは音驚愕反応を示し, 耳石 器の形態異常を示すNox3ノックアウトマウスは音驚愕 反応を示さなくなる事が報告されて打り $(24), 100 \mathrm{~Hz}$ 以下の低周波騒音が直接的に前庭の有毛細胞を刺激する かについても, 今後の興味ある課題である。

\section{おわりに}

本稿では，内耳機能に影響する物理的環境因子とし て, 可聴域騒音が誘発する騒音性難聴と低周波騒音曝露 が誘発する平衡感覚障害の現状と実験研究について, 我々の過去の実験研究も交えて紹介した。紫外線などの 物理的環境因子では，波長域毎の皮膚老化などの健康り スクについて既に報告されている。一方，騒音の健康リ スクについては，周波数を考慮した情報は未だ限られて いるため，今後は，騒音の周波数も考慮した健康りスク 評価を実験研究と疫学研究に実施する事が重要であると 思われる。

\section{謝辞}

本研究は, 文部科学省抽よび日本学術振興会より, 新学 術領域（宇宙に生きる, 課題番号：16H01639）基盤研究 C (課題番号：25460178，16K08343）の科学研究費, 私立 大学戦略的研究基盤形成支援事業「生活習慣病予防の科 学的食育プログラム確立を目指す基礎栄養科学研究拠点 形成」(課題番号:S1201007) の支援を受けて実施された。
利益相反：なし

\section{文献}

(1) Lalwani AK, Gürtler N. Sensorineural hearing loss, the aging inner ear, and hereditary hearing impairment. In: Lalwani AK (ed), CURRENT Diagnosis \& Treatment in Otolaryngology-Head \& Neck Surgery, second edition. New York: McGraw-Hill, 2008, 683-704.

(2) Ohgami N, Ida M, Shimotake T, Sakashita N, Sone M, Nakashima T, et al. c-Ret-mediated hearing loss in mice with Hirschsprung disease. Proc Natl Acad Sci USA 2010; 107:13051-13056.

( 3 ) Ohgami N, Iida M, Yajima I, Tamura H, Ohgami K, Kato M. Hearing impairments caused by genetic and environmental factors. Environ Health Prev Med 2012;18:10-15.

( 4 ) Ohgami N, Ida-Eto M, Sakashita N, Sone M, Nakashima N, Tabuchi K, et al. Partial impairment of c-Ret at tyrosine 1062 accelerates age-related hearing loss in mice. Neurobiol Aging 2012;33:626.e25-34.

( 5 ) Roux I, Safieddine S, Nouvian R, Grati M, Simmler MC, Bahloul A, et al. Otoferlin, defective in a human deafness form, is essential for exocytosis at the auditory ribbon synapse. Cell 2006;127(2):277-289.

（6）喜多村健，森山 寛（編）. NEW 耳鼻咽喉科・頭頸 部外科学 (改訂第 2 版)。東京 : 南江堂, 2007.

( 7 ) Ohgami N, Kondo T, Kato M. Effects of light smoking on extra-high-frequency auditory thresholds in young adults. Toxicol Ind Health 2011;27:143-147.

( 8 ) Lynch ED, Jonathan K. Compounds for the prevention and treatment of noise-induced hearing loss. Drug Discovery Today 2006;10:1291-1298.

( 9 ) Henderson D, Bielefeld EC, Harris KC, Hu BH. The role of oxidative stress in noise-induced hearing loss. Ear Hear 2006;27:1-19.

(10) Yang WP, Henderson D, Hu BH, Nicotera TM. Quantitative analysis of apoptotic and necrotic outer hair cells after exposure to different levels of continuous noise. Hear Res 2004;196:69-76.

(11) $\mathrm{Hu}$ BH, Guo W, Wang PY, Henderson D, Jiang SC. Intense noise-induced apoptosis in hair cells of guinea pig cochleae. Acta Otolaryngol 2000;120:19-24.

(12) $\mathrm{Hu} \mathrm{BH}$, Henderson D, Nicotera TM. Involvement of apoptosis in progression of cochlear lesion following exposure to intense noise. Hear Res 2002;166:62-71.

(13) Brown KD, Maqsood S, Huang JY, Pan Y, Harkcom W, Li $\mathrm{W}$, et al. Activation of SIRT3 by the $\mathrm{NAD}^{+}$precursor nicotinamide riboside protects from noise-induced hearing loss. Cell Metab 2014;20(6):1059-1068.

(14) Delmaghani S, Defourny J, Aghaie A, Beurg M, Dulon D, Thelen $\mathrm{N}$, et al. Hypervulnerability to sound exposure through impaired adaptive proliferation of peroxisomes. Cell 2015;163(4):894-906.

(15) Kramer S, Dreisbach L, Lockwood J, Baldwin K, Kopke R, Scranton S, et al. Efficacy of the antioxidant N-acetylcysteine (NAC) in protecting ears exposed to loud music. J Am 
Acad Audiol 2006;17(4):265-278.

(16) Tamura H, Ohgami N, Yajima I, Iida M, Ohgami K, Fujii N, et al. Chronic exposure to low frequency noise at moderate levels causes impaired balance in mice. PLoS One 2012; 7:e39807.

(17) Ko DC, Milenkovic L, Beier SM, Manuel H, Buchanan J, Scott MP. Cell-autonomous death of cerebellar purkinje neurons with autophagy in Niemann-Pick type C disease. PLoS Genet 2005;1:81-95.

(18) Mariño G, Fernández AF, Cabrera S, Lundberg YW, Cabanillas R, Rodríguez F, et al. Autophagy is essential for mouse sense of balance. J Clin Invest 2010;120:2331-2344.

(19) Deron RH, Nicolas G, Martin S, Richard R, Ulrich M, Jerold C. Sphingosine 1-phosphate (S1P) signaling is required for maintenance of hair cells mainly via activation of S1P2. J Neurosci 2007;27:1474-1478.

(20) Zhao X, Jones SM, Yamoah EN, Lundberg YW. Otoconin90 deletion leads to imbalance but normal hearing: a comparison with other otoconia mutants. Neuroscience 2008; 153:289-299.

(21) Ebrahim S, Avenarius MR, Grati M, Krey JF, Windsor AM,
Sousa AD, et al. Stereocilia-staircase spacing is influenced by myosin III motors and their cargos espin-1 and espinlike. Nat Commun 2016;7:10833.

(22) Paffenholz R, Bergstrom RA, Pasutto F, Wabnitz P, Munroe RJ, Jagla W, et al. Vestibular defects in head-tilt mice result from mutations in Nox3, encoding an NADPH oxidase. Genes Dev 2004;18(5):486-491.

(23) Legan PK, Lukashkina VA, Goodyear RJ, Kössi M, Russell IJ, Richardson GP. A targeted deletion in alpha-tectorin reveals that the tectorial membrane is required for the gain and timing of cochlear feedback. Neuron 2000;28(1):273285

(24) Jones GP, Lukashkina VA, Russell IJ, Lukashkin AN. The vestibular system mediates sensation of low-frequency sounds in mice. J Assoc Res Otolaryngol 2010;11(4):725732.

(25) Honda K, Noguchi Y, Kawashima Y, Takahashi M, Nishio A, Kitamura K. Ex vivo visualization of the mouse otoconial layer compared with micro-computed tomography. Otol Neurotol 2015;36(2):311-317. 